\title{
1. Introduction: focusing on the role of resources and universities in entrepreneurship
}

\author{
Ulla Hytti, Robert Blackburn, \\ Denise Fletcher and Friederike Welter
}

\section{INTRODUCING THE CHAPTERS}

Research on social entrepreneurship has been booming in recent years. In Chapter 2, Johannisson, Alpenberg and Strandberg aim to contribute to this area by recognizing its processual character through the new concept of 'social entrepreneuring'. Through an interactive, in-depth case study of two social enterprises and by drawing on practice theory, the authors investigate the practices of social entrepreneuring to identify their structural and processual features. The chapter suggests three conceptual dualities as structural cornerstones in social entrepreneuring: the individual and the collective as subject/actor; personal and institutional rules of action; and self-identity and social identity. In terms of processual features, six practices are identified: social bricolaging, amplified immediacy, dynamic involvement, ambiguous legitimacy, selfenforced heterogeneity and urgency for financial viability. The chapter concludes by emphasizing the importance of collective effort and local adaptation in social enterprises compared with commercial businesses. Interestingly, however, the need for financial capital is considered no less important in social than commercial enterprises and considered much more important than the role of social capital.

Accessing external finance is challenging particularly for new ventures. Thus, the role of online social networks, providing access to a new funding stream referred to as 'crowdsourcing', has raised a great deal of interest recently. In Chapter 3 Huynh discusses one particular form of crowdfunding, namely equity crowdfunding. The chapter conceptualizes this new phenomenon, reviews past research in this field and suggests an agenda for further research in equity crowdfunding in the 
entrepreneurship context. It points towards three perspectives: crowdfunders, entrepreneurs and government. First, there is a need to understand the decision-making of funders in equity crowdfunding, including motives, incentives and processes. Second, more research is needed on successful crowdfunding plans, proposals and processes that are attractive to investors as well as the risk management that is needed to help entrepreneurs in obtaining and managing equity crowdfunding. Finally, further research should inform policy of the regulatory environment for equity crowdfunding.

While finance is important for new ventures, the non-financial resources of investors such as business angels and venture capital firms have been highlighted in the literature. Based on a longitudinal, intensive case study by Nevalainen and Eriksson, Chapter 4 investigates how the role and non-financial contributions of a group of business angels change over time as their experience of the business, as well as their cooperation with the business, evolves. The chapter highlights the dynamic and interactive nature of the relationship by suggesting that it is not only the contributions that change over time but also the ways in which the business angels provide their input. The research shows that entrepreneurs also have an influence over the contributions the business angels provide. Thus, the contributions of both parties change as the business angels and the entrepreneurs interact and interpret the situation at hand.

Internationalization is an important growth strategy for new and small ventures. However, internationalization requires resources. In Chapter 5, Yavuz, Sapienza and Chu discuss how resources impact on internationalization. More specifically they investigate how resource flexibility can facilitate and enhance internationalization in start-ups. The chapter finds that a greater degree of flexibility in new ventures facilitates their identification of international opportunities earlier in their life cycles and also improves their performance after the entry into the new markets. Consequently, the authors suggest that resources are an important element distinguishing internationalization of new ventures from more established firms, and resource allocation decisions are the most critical decisions for entrepreneurs for success in early internationalization.

Alliances represent one potential strategy for overcoming resource constraints in small firms. However, research evidence suggests that the size asymmetries between large and small firms can undermine the role of the small firm and represent a 'smallness challenge'. In Chapter 6, Salamonsen addresses alliances between large and small firms to investigate how geographical, organizational and technological proximity influence small firms' relationships with large partners. Drawing from case studies conducted from small firms in five asymmetrically sized 
alliances in the Norwegian oil and gas industry, the author suggests that the non-spatial dimensions of proximity can mitigate the smallness challenge. Personal relationships, common industry experience, shared understanding of technology and mutual dependence were identified in this chapter as central elements in those small firms that succeeded in their collaboration with large partners. Hence, the findings suggest that in small firms, managers should form social relationships and legitimacy in the industry before entering into alliances.

Academic entrepreneurship and the role of universities in entrepreneurship is an important contemporary research theme. Based on biographical data of 12 Finnish and 11 Russian science-based entrepreneurs, Karhunen and Olimpieva investigate the role identities of science-based entrepreneurs in two different institutional contexts in Chapter 7. The authors suggest an emergence of new hybrid role identity, that of the 'scientrepreneur'. The chapter identifies the ways in which context and institutions influence role identity construction. In Finland, the two identities seem to be mutually supportive and the two roles cannot be separated. The commercialization of research is viewed as an integral part of the work as a scientist and parallels are drawn between the science and entrepreneurship. On the other hand, in Russia the role of the scientist is placed at the core, and in need of protection from entrepreneurial role demands. Hence, the entrepreneurial role is that of forced identity. Thus, the chapter illustrates the role of institutional context as an important factor.

The study of entrepreneurial intentions is one of the enduring themes in entrepreneurship research as shown in past Frontier volumes. However, longitudinal studies and investigations addressing the link between intentions and actual start-up behaviour have been few. In Chapter 8, Varamäki, Joensuu-Salo and Viljamaa address this gap by examining the realization of students' entrepreneurial intentions in entrepreneurial behaviour after graduation. The chapter finds that entrepreneurial intentions measured during education explain the graduates' entrepreneurial behaviour. The chapter also indicates that perceived behavioural control is more important in actual behaviour than in intentions. This suggests that cultivating students' capabilities and their perceptions of their own capabilities in entrepreneurship are important tasks for entrepreneurship educators. Additionally, the chapter suggests that entrepreneurship educators should tailor their efforts to different groups: those who start their ventures while in education and those with high and low entrepreneurship intentions.

University-industry cooperation is increasingly regarded as an important mechanism for local and regional economic development. In Chapter 9, 
Horner and Giordano discuss the ways in which a university-industry partnership can play a role in enhancing open innovation efforts and capabilities at the regional level. Based on a social constructivist analysis of a single case study the chapter suggests that geography and physical space play an important role in the formation and functioning of the open innovation partnership. Geographic proximity facilitates the formation of trust and personal relationships and transfer of tacit knowledge and ease in making contacts. Funding, other forms of public support and creation of a common technology platform also play an important role in forming research partnerships. In addition to these institutional arrangements, individuals and individual agency are important to the establishment and functioning of open innovation partnerships. The chapter suggests that universities can impact entrepreneurship and innovation beyond the formal transfer of intellectual property by providing tacit know-how, technological capabilities and open access facilities.

\section{INTRODUCING RENT XXVIII IN LUXEMBOURG}

This volume presents a selection of significant chapters developed from the 113 papers presented at the RENT Conference XXVIII hosted by the University of Luxembourg in November 2014. The RENT Conference is one of the key entrepreneurship research conferences in the world, attended by 170 delegates. The anthology reflects the variety of contemporary topics and approaches that researchers of entrepreneurship are focusing on today. The selection of the chapters for the anthology is based on a peer-review evaluation of the conference papers and their contributions to the knowledge, theory and practice. The Frontiers in European Entrepreneurship Research anthology series aims to contribute to and extend discussions in entrepreneurship research with the idea of consolidating knowledge. But the ambition is also to offer room for new ideas and concepts to help the entrepreneurship research field evolve into new directions. This volume is not an exception in this respect.

First, the concept of 'social entrepreneuring' is presented (Chapter 2) and discussed in this volume as a new opening. Second, the resourcebased view has been influential in entrepreneurship research to highlight first that resources are important for the success of new and small ventures and second that most new and small firms face resource constraints. Four chapters (3-6) in this volume draw upon this concept to answer specific questions. Third, from the societal perspective, there is an expectation that universities, with their knowledge base, represent an important resource for promoting entrepreneurship and innovation in the 
region or society at large. Universities are increasingly considered sources of entrepreneurship, in terms of new entrepreneurs from faculty members and from the pool of graduates. Universities are also seen to contribute to entrepreneurship and innovation by cooperating with businesses. Three chapters (7-9) in this volume address the role of universities in entrepreneurship.

\section{OUTLOOK}

Overall, this anthology offers varied and novel insights to our understanding of financial, knowledge and other resources in developing and sustaining entrepreneurship and innovation. The chapters offer new insights, conceptual and empirical, into the ways of overcoming resource constraints typical for new and small ventures, for example by relying on new forms of funding, interacting with investors or by developing strategic alliances in ways that are beneficial also for small firms. They also emphasize the crucial importance of resource allocation. Universities are increasingly seen as important for innovation and entrepreneurship either directly by contributing to the entrepreneur population or by indirectly serving as engines for growth and innovation by cooperating with the business and regions. The chapters also provide new information of these processes. The chapters illustrate the variety of research methods in the field, including the much called for longitudinal research settings both in qualitative and quantitative studies. 